\title{
How to finance investment in Bangladesh: Finding long- run factors in a bounds test method
}

\author{
Biru Paksha Paula* \\ a Department of Economics, State University of New York at Cortland, NY 13045, USA. \\ * Corresponding author email: biru.paul@cortland.edu
}

\author{
H I G H L I G H T S: \\ 1. Bangladesh's growth has remained almost stagnant, because its investment rate has remained stagnant as well. \\ 2. The country has to reduce lending rates and undertake credit expansion policies to enhance investment. \\ 3. Growing demand for Bangladeshi exports has helped increase capital formation in the country. \\ 4. Further liberalization in trade and finance is needed to accelerate investment growth in Bangladesh.
}

\section{Article History \\ Received: 27-04-2014 \\ Accepted: 01-06-2014 \\ Available online: 02-06-2014 \\ Keywords: \\ ARDL Bounds test method; \\ Bangladeshi economy; \\ Capital formation; \\ Investment determinants.}

JEL Classification:

E22; E50; 016; P45.

\begin{abstract}
Investment in Bangladesh has been at almost one-fourth of the country's output since the early 2000s. Consequently, Bangladesh's growth has also remained stagnant at around 6 percent since then. The question of how to increase investment in Bangladesh has been of crucial discussion of late. This study examines the long run determinants of investment in Bangladesh by applying the bounds test over 1976-2010. There should not be any policy dilemma about the effect of lending rates, which must be reduced to boost investment and domestic credit should be expanded. Further liberalization in trade and finance is recommended since economic openness and financial deepening show a positive impact on capital formation. The policy prescriptions for Bangladesh are not different from those for other nations that embarked on liberalization to augment investment for accelerating growth.
\end{abstract}

DOI: http://dx.doi.org/10.18533/jefs.v2i02.136

allows use, distribution and reproduction in any medium, provided the original work is properly cited.

\subsection{Introduction}

Bangladesh is an emerging market economy in South Asia. Its growth is one of the fastest not only in the region, but also in the world. The country grew at the rate of 5 percent over the last quarter century since 1986 (WDI 2012 ). Over the last decade, Bangladesh's growth reached close to 6 percent, suggesting an impressive rate of growth, which in turn has created an increasing demand for investment in the country. The investment-Gross Domestic Product (GDP) ratio, which is often defined as the investment rate, has remained in the doldrums in Bangladesh at around 24-26 percent for a decade or so. The capital-output ratio, which gives the amount of capital needed to produce one unit of output, in the region turns out to be around 4. Consequently, this investment rate of 26 percent is capable of generating output growth of 6 percent or slightly above.

\footnotetext{
\& The author is thankful to Bangladesh Bank governor Dr. Atiur Rahman for his valuable advice. The support of the Research Division of Bangladesh Bank and Rama Rani Sutradhar in particular is greatly acknowledged. The author has been benefited from the comments of the participants at the international conference on Bangladesh held on February 22-24, 2013 at University of California-Berkeley.
} 
There are no other magical tools to earn and secure sustainable growth of 7 percent or above without lifting the investment-GDP ratio above the current level. In the recent years, Pakistan hardly managed a growth rate below 4 percent with its investment rate at around 13-14 percent. In contrast, India registered 8 percent growth mainly because of its high investment ratio at around 34-36 percent. So the same is true for China. Given this perspective, there are sufficient concerns around national and international corners as to how Bangladesh can increase investment to accelerate its economic growth.

This scenario has raised a number of questions such as: 1) what are the factors that affect Bangladesh's investment significantly in the long run? 2) What policy measures are important to nurture these influential factors? 3) Did liberalization contribute to accelerated capital formation in Bangladesh? The existing literature on the long run determinants of Bangladesh's investment is conspicuously absent. This study fills that gap by addressing the questions.

This work collects a dataset of 13 variables, which are supposed to influence investment in a developing economy, over the period from 1976 to 2010. The issues on the sample size and the selection of variables have been discussed subsequently in detail. The term, capital formation, is used in this paper to mean a change in annual capital stock, which means investment as well. Accordingly, these two terms have been used interchangeably in this paper. Finally, this work examines the determinants of investment in Bangladesh in an Autoregressive Distributed Lag (ARDL) bounds test approach, a modern econometric method to test long-run relationships among selected variables.

In this part, the results of the study can be briefly previewed as follow: this study finds that the lending rate adversely affects investment in Bangladesh in the long-run. Short-run effects of the lending rate on investment are insignificant. Both domestic credit and financial deepening have both long-run and short-run positive impact on capital formation in the country. Both trade and economic openness influence capital formation of the country in a positive fashion. A further investigation reveals that only exports are the significant factor that makes the trade and openness variables significant. The level relationship between foreign aid and investment is significant but negative.

Other variables such as savings, imports, Foreign Direct Investment (FDI), remittances, and market capitalization do not maintain any of the long-run relationships with investment in Bangladesh in a significant way. It appears that the policies on liberalization, export promotion, deregulation, and financial deepening have been beneficial to foster capital formation in an emerging economy like Bangladesh. These findings have policy implications not only for Bangladesh, but also for other developing nations that endeavor to boost capital formation to sustain and often accelerate economic growth in their economies.

This paper comprises six sections. The next section presents a brief literature review. Section 3 discusses data and methodology aspects. Section 4 presents estimations and results. The implications of the results are delivered in Section 5. Section 6 concludes.

\section{$2.0 \quad$ Literature review}

The causal effect on how investment or capital formation can contribute to economic growth has been addressed in Krugman (1994), Parida and Sahoo (2007), Das and Paul (2011) and Sahoo and Dash (2012). As a specific work on the South Asian region, Paul (2013) shows that the economic growth-differential between Bangladesh and India is mainly explainable by the investment-growth differential between them. Hence, it becomes necessary to understand both the short-run and long-run contributing factors to investment to promote output growth.

There are not many time-series studies on Bangladesh's investment. The main reason behind this deficiency is the absence of an adequate number of observations. While there is no explicit statement in econometrics on how many observations are needed to get reliable results with annual time-series data, the usual practice is to collect at least 30 observations to make econometric estimates acceptable and robust. As discussed in the introduction, the most annual time series on Bangladesh's macro variables did not become either available or free of massive outliers until the mid or late 1970s. As a result, exercises on Bangladesh's annual time series began to emerge remarkably since the mid-2000s to ensure around 30 observations in the sample. Despite this deficiency, we notice a number of papers on investment or capital formation in mainly South Asian economies and particularly in Bangladesh as discussed below.

Investment determinants can be country specific as argued in Naqvi and Tsoukis (2003). They examined growth and investment performances of six Asian nations: Bangladesh, India, Indonesia, Malaysia, Pakistan, and Thailand. While public and private investments are likely to feed each other, there exist no single relationship between these variables that hold consistently across these countries. Bhattacharyay and De (2005) argue that the open regionalism and integration between China and India can foster investment and growth. They propose to include 
other neighboring countries such as Bangladesh, Bhutan, Myanmar, and Nepal for promoting capital formation and growth through regional integration.

Dollar et al. (2005) run a study with various micro aspects of the investment climate in China, India, Pakistan, and Bangladesh. They find that the investment is low where the cost of different bottlenecks is high. They show that for many of these costs, the obstacles are lower in China than in Pakistan, India, and Bangladesh. Factor returns are also higher where the investment climate is better. Siriwardana and Yang (2007) argue that thefree trade is beneficial for investment augmentation. They show that the Indian investment in Bangladesh can enhance new supply and export capacities under free trade arrangements.

Wadud (2009) runs a study with India, Pakistan, and Bangladesh over 1976-2008. He finds that the financial development affects economic growth positively in these countries. In essence, financial deepening contributes to investment expansion to increase output. De et al. (2012) find that greater trade integration between Bangladesh and India can promote investment and productivity in both countries. Sahoo and Dash (2012) work with four South Asian countries: India, Pakistan, Bangladesh, and Sri Lanka over 1980-2005. They find a long run equilibrium relationship between output and infrastructure along with capital formation.

Correa and Rao (2004) assert that the neoclassical proposition of the influence of interest rates on investment has little support in the Indian experience. Cole (2009) shows that the credit markets with nationalized banks experienced faster credit growth during a period of financial repression in India, suggesting that lower interest rates do not necessarily increase investment. He argues that India's bank nationalization in 1980 led to lower interest rates and lower-quality intermediation, and may have slowed employment gains in trade and services. Qayyum (2002) finds significant responsiveness of investment to changes in interest rates in Pakistan over a decade before 2002. He shows that a high rate of interest on bank lending negatively affects the demand for bank credit by the business sector, which reduces investment and in turn leads to low aggregate demand and lower output.

Using quarterly dataset for the period of 1976Q4 to 2005Q2, Ahmed and Islam (2004) investigate whether interestrate liberalization pursued under the Financial Sector Reform Programs (FSRPs) of the early 1990s has been able to create a competitive environment in the financial market of Bangladesh. Their results, however, suggest that investment spending at the aggregate level be non-responsive to interest rates. As they also find, investment spending at the disaggregate level is still not responsive to interest rates except for the private sector investment category, which is only moderately responsive from the lender's point of view in the short run. This study, nevertheless, covers a longer timespan to examine the determinants of investment in Bangladesh.

Kamal (2011) investigates the effect of real interest on investment in Bangladesh for the period from 1976 to 2006. He finds evidence of weak but negative sensitivity of investment to the interest rate in Bangladesh both in the short run and long run. The findings of this work, which contradict some of the previous results, warrant further investigation by extending the sample beyond 2006. Although Kamal uses the ARDL method as is used here, he mainly focuses on the interest-investment nexus only. The approach in this paper includes all possible factors of investment in a more comprehensive way with an extended sample size.

The mixed results on the interest rate-investment relationship have been subject to further investigation when the Budget of Bangladesh's Finance Ministry for the fiscal year 2012-2013 argues that the investment-interest rate correlation is not much significant. This policy document claims that the Bangladesh economy is now in the takeoff stage, and there are ample opportunities for earning high returns on investments. Hence, as the Budget claims, high interest rates are not likely to impede investment in the country (Budget 2012:10).

The studies show that there could be a number of factors to influence investment in South Asia and particularly in Bangladesh. Thus, the influencing factors of investment being different across countries warrant further inquiry for Bangladesh.

\subsection{Materials and methods}

Data from the World Development Indicators (WDI 2012) of the World Bank were collected. The time series on investment is termed as capital formation in the WDI. The dataset begins in 1976 and ends in 2012. Although Bangladesh became independent in 1971, most economic series exhibit serious volatility and numerous outliers in the initial years of independence since the country had been recovering from a war-ravaged situation. Some variables are not available until 1976. As a result, most time-series studies on Bangladesh begin in 1976 or even after that (see Ahmed and Uddin 2009, Mamun and Nath 2005, Paul 2011, 2012). 
There lies another reason for why time-series studies on Bangladesh begin sometime in the post-1975 period. The first regime in the post-independence period took a rigorous path of massive nationalization, centralized control, and socialist planning. This regime ended in 1975, and the country slowly began to proceed towards the market economy and liberalization in a piecemeal approach since 1976. Ahmed and Sattar (2004) assert that Bangladesh's first phase of liberalization began in 1976 after the regime change in 1975. The interactions between economic variables are expected to show more plausible results in a relatively liberalized environment. That also explains why this exercise begins in 1976. The starting point of 1976 leaves us to work on each series with 35 annual observations, a number viewed as a sound sample size for time-serie's estimations.

Since the main objective of this paper is to find the long-run factors behind capital formation, a number of macro variables are collected that are, based on theory and practice, expected to influence investment in Bangladesh. The typical goods market theory dictates including income or Gross Domestic Product (GDP) and interest rates in the first place. The expansion of domestic credit is viewed as a dominant candidate to affect capital formation in emerging economies like Bangladesh. In Keynesian theory, saving may not necessarily be a significant determinant of investment. The Solow model recommends including saving to determine the change in capital stock (Solow 1956). Foreign aid or Official Development Assistances (ODA) and remittances are two major inflows that are expected to contribute to capital formation in Bangladesh.

Based on the recent experience of growth in the country in the wake of liberalization and financial deregulation, the inclusion of variables like trade, foreign direct investments (FDI), and market capitalization becomes imperative. The measure of openness has various versions (Harrison 1996). The most basic measure of openness is the simple trade share, which is exports plus imports divided by GDP (Yanikkaya 2003). The total trade volume is also viewed as a measure of economic openness (see Liu et al. 1997, Sinha and Sinha 2002, Din at el. 2003). The level of financial development in the country is usually measured by the share of domestic credit in the country's GDP (see Adeniyi et al. 2012).

Given this perspective, this study includes 11 variables that are expected to influence investment in Bangladesh such as: 1) GDP 2) the lending rate 3) domestic credit 4) domestic saving 5) remittances 6) foreign aid 7) the total trade volume 8) the trade-GDP ratio or the measure of economic openness 9) the share of domestic credit in GDP, which can be called as the credit-GDP ratio or financial deepening 10) FDI and 11) market capitalization. The variable of trade volume has also been decomposed into exports and imports, making total number of variables be 13. All the basic variables except for the lending rate are first converted into 2000 constant U.S. dollars. The logarithmic values of all the variables are taken afterward. Due to some negative figures, which refuse log conversion, in the series of net FDI until 1985, the series begins in 1986. The series of market capitalization is not available in the WDI until 1988.

The studies that sequentially developed the ARDL bounds test approach include Pesaran and Pesaran (1997), Pesaran and Shin (1999), and Pesaran et al. (2001). There are numerous advantages in the ARDL method, which makes it more useful than others. With a small sample size, as is the case with mine, this method is more efficient than other techniques. In contrast, the Johansen cointegration technique, which is due to Johansen and Juselius (1990), requires larger samples for the results to be valid (Ghatak and Siddiki 2001). The simplicity of this ARDL bounds test method is appealing. As opposed to other multivariate cointegration techniques, it allows the cointegrating relationship to be estimated by the OLS method once the lag order of the model is identified.

As Pesaran et al. (2001) assert, this asymptotic theory provides a simple univariate framework for testing the existence of a single level relationship between a variable and its regressors when it is not known with certainty whether the regressors are purely integrated of order one, $I(0)$, purely $I(1)$, or mutually cointegrated. In contrast, the Johansen test can work only with nonstationary I(1) series. Moreover, it is unnecessary that the order of integration of the underlying regressors be ascertained prior to testing the existence of a level relationship. Therefore, unlike typical applications of cointegration analysis, this method is not subject to this particular kind of pretesting problem.

Thus, a long-run relationship can be established with this technique irrespective of the time series properties of the variables in the model. Even when some of the model regressors are endogenous, the bounds testing approach generally provides unbiased long-run estimates and valid $t$-statistics (Narayan 2005, Odhiambo 2008). Moreover this approach provides a method of simultaneously assessing the short-run and the long-run effects of one variable on the other. At the same time, the ARDL has an appealing separation of short-and long-run effects (Bentzen and Ergsted 2001). The long-run relationship can be estimated in the following forms:

$\operatorname{cap}_{t}=\alpha_{i 1}+\beta_{i} x_{t}+\theta_{i}$ trend $+\varepsilon_{i t}$ 
Where, cap denotes capital formation, $x$ stands for the 13 variables that are likely to affect capital formation as mentioned in the introduction. Hence, $\alpha_{i}(\mathrm{i}=1 \ldots 13)$ stands for intercept terms, $\beta_{i}(\mathrm{i}=1 \ldots 13)$ signifies coefficients on respective variables, $\theta_{i}(\mathrm{i}=1 \ldots 13)$ stands for the trend terms, and finally $\varepsilon_{i t}(\mathrm{i}=1 \ldots 13)$ denotes error terms. To implement the bounds testing procedure, the following conditional ARDL-error correction models (ECMs) are presented, which correspond to the previous equation:

$$
\Delta c a p_{t}=c_{i}+\pi_{1} \operatorname{cap}_{t-1}+\pi_{2 i} x_{i t-1}+\pi_{3 i} \text { trend }_{t-1}+\sum_{i=1}^{p} \theta_{i} \Delta c a p_{t-i}+\sum_{i=1}^{p} \phi_{i} \Delta x_{t-i}+\sum_{i=1}^{p} \delta_{i} \Delta \text { trend }_{t-i}+u_{i t}
$$

Where, $\Delta$ denotes the first difference operator. $c_{i}(\mathrm{i}=1 \ldots 13)$ shows constants, $\pi_{i}(\mathrm{i}=1 \ldots 13)$ signifies coefficients on the lagged levels, $\theta_{i}, \phi_{i}$ and $\delta_{i}(\mathrm{i}=1 \ldots p)$ denote coefficients on the first differences of the lagged variables and trend, and finally $u_{i}(\mathrm{i}=1 \ldots 13)$ stands for error terms. $p$ signifies the maximum lag length, which is decided by the user. The researcher usually depends on literature and convention to determine the maximum lag length. The selection criteria such as Schwarz Bayesian Criterion (SBC) and Akaike Information Criterion (AIC) are mainly used to determine the order of the ARDL model. Given the sample size, the SBC is used to determine the lag length of the ARDL, because the SBC chooses the most parsimonious model (see Enders 2010:120, Lutkepohl 1985).

Following Pesaran et al. (2001), $F$ and $W$ (Wald) statistics are employed to 'bounds test' for the existence of a longrun relationship where the null hypothesis states that the coefficients on the lagged levels are zero: $H_{0}: \pi_{1}=\pi_{2}, \pi_{1}=$ $\pi_{3}, \ldots \ldots . . . \pi_{1}=\pi_{13}=O$. Pesaran et al. (2001) provide lower and upper bound critical values where the lower bound critical values assume all variables are $I(0)$ while the upper bound critical values assume all variables are $I(1)$. If the calculated $F$ or $W$ statistic exceeds the upper bound, the null hypothesis of no cointegration can be rejected. If they fall below the lower bound, the null hypothesis of no long-term relationship cannot be rejected. However, if they fall within their respective bounds, inference would be inconclusive. Now estimating long-run coefficients and the ECM along with the short-run parameters becomes necessary. The sign of the error correction (EC) coefficient must be negative and significant to ensure convergence of the dynamics to the long-run equilibrium.

\subsection{Results and discussion}

As discussed before, testing the variables for unit roots in the ARDL estimation is unnecessary, because this estimation can accommodate any variables, which are I(1), I(0), or mutually cointegrated. However, one limitation of the ARDL method is that it cannot be estimated with I(2) series. Although the series this study has undertaken are most likely to be I(1) or I(0), testing them to ensure that none of them are I(2) is required. The Augmented Dickey-Fuller (ADF) test is widely used in this regard (Dickey and Fuller 1979, 1981).

Phillips and Perron (1988) proposed a modification of the Dickey-Fuller (DF) test and have developed a comprehensive theory of unit roots. The Phillips-Perron (PP) test has introduced a t-statistic on the unit-root coefficient in a DF regression, corrected for autocorrelation and heteroskedasticity. Formally, the power of a test is equal to the probability of rejecting a false null hypothesis. 


\section{TABLE 1}

Phillips-Perron unit root tests with investment and its related series in Bangladesh: 1976-2010

\begin{tabular}{|c|c|c|c|c|c|}
\hline \multirow[b]{2}{*}{ Variables } & \multicolumn{2}{|c|}{ In levels } & \multicolumn{2}{|c|}{ In first difference } & \multirow[b]{2}{*}{ Integration } \\
\hline & Model A & Model B & Model A & Model B & \\
\hline Capital formation & $-2.23(0.20)$ & $-4.62(0.00)$ & $-4.39(0.00)$ & $-3.81(0.03)$ & $\mathrm{I}(1) / \mathrm{I}(0)$ \\
\hline Gross domestic product & $7.15(1.00)$ & $0.87(1.00)$ & $-4.36(0.00)$ & $-5.91(0.00)$ & I(1) \\
\hline Lending rate & $-0.45(0.89)$ & $-2.42(0.36)$ & $-5.37(0.00)$ & $-5.31(0.00)$ & I(1) \\
\hline Domestic credit & $0.67(0.99)$ & $-1.26(0.88)$ & $-5.79(0.00)$ & $-6.15(0.00)$ & I(1) \\
\hline Domestic savings & $-0.43(0.89)$ & $-3.36(0.07)$ & $-8.03(0.00)$ & $-16.05(0.00)$ & $\mathrm{I}(1)$ \\
\hline Trade & $0.47(0.98)$ & $-3.09(0.12)$ & $-7.64(0.00)$ & $-7.42(0.00)$ & I(1) \\
\hline Exports & $0.19(0.97)$ & $-2.03(0.56)$ & $-7.66(0.00)$ & $-7.94(0.00)$ & I(1) \\
\hline Imports & $0.18(0.97)$ & $-3.94(0.02)$ & $-9.07(0.00)$ & $-9.50(0.00)$ & $\mathrm{I}(1) / \mathrm{I}(0)$ \\
\hline Foreign aid & $-1.88(0.34)$ & $-3.99(0.02)$ & $-9.16(0.00)$ & $-8.88(0.00)$ & $\mathrm{I}(1) / \mathrm{I}(0)$ \\
\hline Foreign direct investment & $-0.53(0.87)$ & $-2.05(0.55)$ & $-5.15(0.00)$ & $-5.18(0.00)$ & I(1) \\
\hline Remittances & $-3.03(0.04)$ & $-5.27(0.00)$ & $-8.46(0.00)$ & $-8.00(0.00)$ & $\mathrm{I}(0)$ \\
\hline Market capitalization & $-0.36(0.90)$ & $-2.22(0.46)$ & $-4.36(0.00)$ & $-4.39(0.01)$ & I(1) \\
\hline Economic openness & $-0.06(0.95)$ & $-2.37(0.39)$ & $-6.97(0.00)$ & $-7.04(0.00)$ & I(1) \\
\hline Financial deepening & $-0.21(0.93)$ & $-1.84(0.66)$ & $-6.16(0.00)$ & $-6.36(0.00)$ & I(1) \\
\hline
\end{tabular}

Note: Model A includes intercept, and Model B includes both intercept and trend. The null hypothesis states that the variable has a unit root. $p$-values are shown in the parentheses under each adjusted $t$-statistic. The critical values and details of the test are presented in Phillips and Perron (1988). I(1)/I(0) indicates that the series's integration order depends on the model chosen. Source: WDI 2012.

Monte Carlo simulations show that the power of the various DF tests can be very low (Enders 2010:234). Maddala and Kim (1998:107) comment that the DF test does not have serious size distortions, but it is less powerful than the PP test. Choi and Chung (1995) assert that for low frequency data, as is the case with this study, the PP test appears to be more powerful than the ADF test. Accordingly, the PP methodology is adopted to test unit roots in the variables.

Table 1 presents the results of the Phillips-Perron unit root tests with the 14 series including capital formation. The results in Table 1 show that 10 out of 14 series are I(1). The rest are either I(0) or I(1) depending on model selection, but none of them are I(2), suggesting their eligibility to be examined in the ARDL bounds test method. The approach provides us with 95 percent critical bounds for the F and W (Wald) statistics. Table 2, however, shows only F-statistics since W-statistics provide the similar results needed to consider the long-run relationships. The critical value bounds are computed by stochastic simulations using 20,000 replications (Pesaran and Pesaran 2009). 


\section{TABLE 2}

ARDL cointegration tests with capital formation in the LHS: 1976-2010

\begin{tabular}{|c|c|c|c|}
\hline Forcing variables & F-Statistic & Forcing variables & F-Statistic \\
\hline Gross domestic product & 6.60 & Foreign aid & 11.67 \\
\hline Lending rate & 24.55 & Foreign direct investment & 4.18 \\
\hline Domestic credit & 8.64 & Remittances & 5.87 \\
\hline Domestic savings & 2.81 & Market capitalization & 4.69 \\
\hline Trade & 12.24 & Economic openness & 21.64 \\
\hline Exports & 21.12 & Financial deepening & 8.86 \\
\hline Imports & 5.73 & & \\
\hline \multicolumn{4}{|c|}{$\begin{array}{l}\text { Note: The null hy pothesis for the } F \text {-test denotes that the coefficients on lagged levels are equal to } \\
\text { zero. The critical value bounds are computed by stochastic simulations using } 20,000 \text { replications } \\
\text { (see Pesaran and Pesaran 2009). The } 95 \text { percent values for the lower and upper bounds are } \mathbf{7 . 3 8} \\
\text { and 8.24, respectively. Statistics are bold when significant at the } 5 \text { percent level. } \Delta \text { denotes the } \\
\text { first order difference operator. Source: WDI } 2012 \text {. }\end{array}$} \\
\hline
\end{tabular}

As Table 2 reports, out of the 13 variables that are likely to affect investment, only 7 variables have been found to have significantly influenced Bangladesh's capital formation over the last 35 years. They are: 1) lending rate 2) domestic credit 3) trade 4) exports 5) foreign aid 6) economic openness and 7) the level of financial development or simply financial deepening. The variables that did not deliver significant effect on investment include: 1) GDP 2) domestic savings 3) imports 4) FDI 5) remittances and finally 6) market capitalization.

Based on the findings of Table 2, all the 7 influential variables are plotted in Figure 1. In Panel A of Figure 1, domestic credit, trade, exports, and foreign aid are plotted along with capital formation. Except for the series of foreign aid, all other series are moving in a positive direction with capital formation, suggesting that the long-run coefficients on these forcing variables will be positive when investment will be regressed on them.

Panel B in Figure 1 plots 3 influential factors of investment. The lending rate is in percent. Other measures are expressed as a percentage of GDP. The figure convinces that both economic openness and financial deepening have been beneficial to capital formation in Bangladesh. The movement between the lending rate and capital formation is divergent over time, suggesting a long-run negative relationship. These relationships are acuter since 1992 when a new form of liberalization had commenced.

Table 3 that presents ARDL estimations of the long-run coefficients and the Error Correction Model (ECM) vindicates the observations of Figure 01 . All the results are robust and consistent in that both long-run and shortrun estimate bear the same positive sign. In Table 3 , the relationship between the lending rate and investment is strongly negative $(-0.55)$ and the coefficient is significant at the 1 percent level.

This finding being theoretically accurate supports Kamal (2011) but contradicts many such as Ahmed and Islam (2004), Correa and Rao (2004), Cole (2009), and Budget (2012). Figure 1: B shows a divergent pattern between the lending rate and investment since the early 1990s. It implies that a lower or slightly falling cost of fund has encouraged the growth of business ventures since the beginning of the new era of liberalization that depressed interest rates down. 


\section{FIGURE 1 \\ Influencial factors to capital formation in Bangladesh: 1976-2010}

Panel A
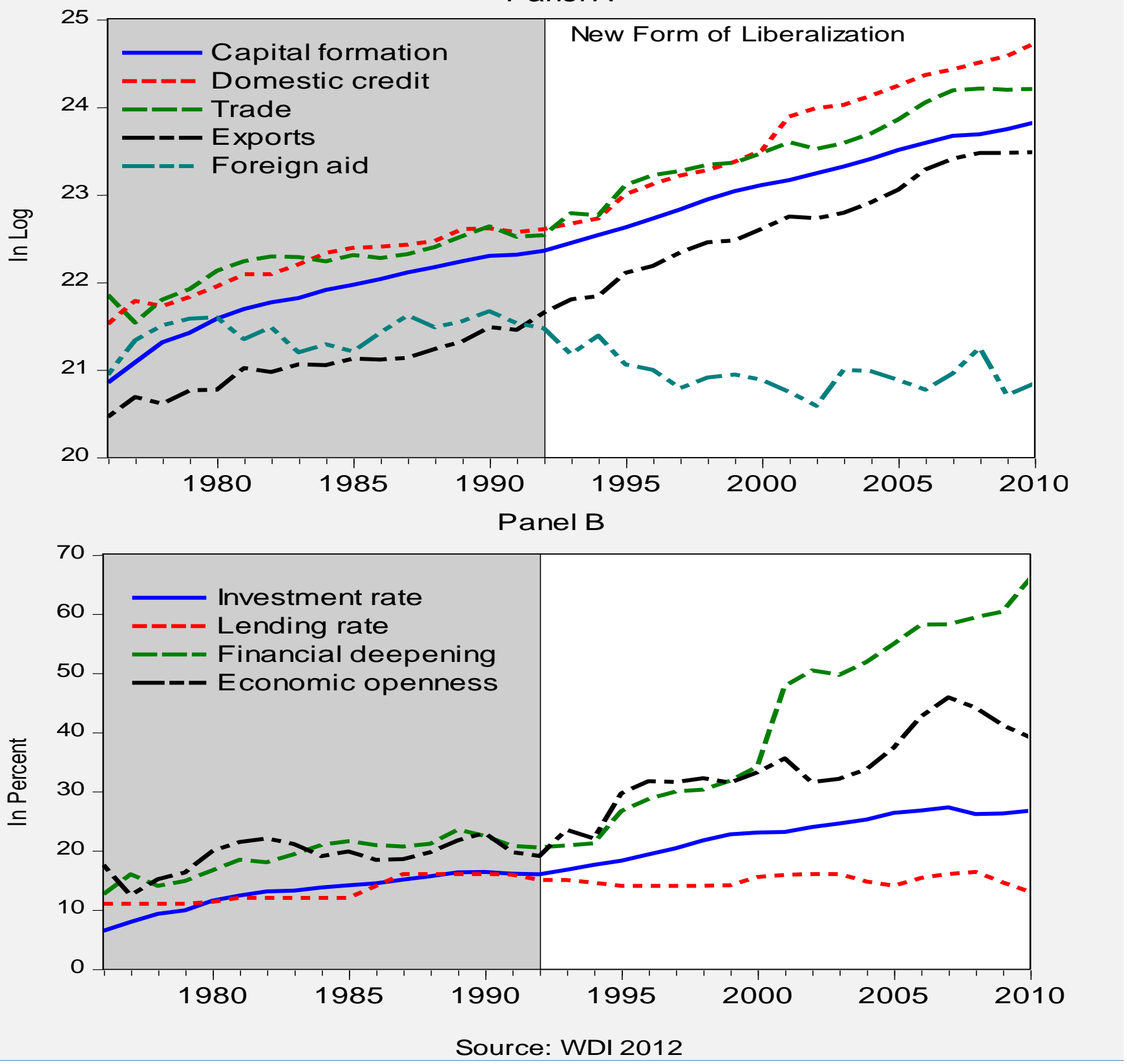

All other coefficients on the RHS forcing variables in Table 3, except for the one on foreign aid, are not only positive but also strongly significant at the 1 percent level. Domestic credit expansion has both short-run and long-run positive impact on capital formation. The long-run positive effect of trade on investment is mainly coming from exports; it vindicates the trade and investment relationships as found in Siriwanrdana and Yang (2007) and De et al. (2012). Growing exports always necessitate more investments to comply with the growing demand for goods by foreigners. The garments industry is a glaring testimony to this case.

Both economic openness and financial deepening have both long-run and short-run positive and significant effects on capital formation, supporting the findings in Bhattacharyay and De (2005) and Wadud (2009). Economic openness creates more incentives for businesses and necessitates an ever-growing demand for investment. In addition, financial deregulation creates more credit opportunities which in turn promote further capital formation in the economy. That is why we notice a simultaneous upward trend in economic openness, financial deepening, and the investment-output ratio since the early 1990s when liberalization rendered a new impetus to investment in Bangladesh. 


\section{TABLE 3}

Long run coefficients and error correction estimates of ARDL models on capital formation in Bangladesh: 1976-2010

\begin{tabular}{|c|c|c|c|c|c|c|c|}
\hline \multirow[b]{2}{*}{$\begin{array}{l}\text { Long-run estimations } \\
\text { with capital formation (t): }\end{array}$} & \multicolumn{7}{|c|}{ RHS variable $=$ Forcing variable } \\
\hline & $\begin{array}{l}\text { Lending } \\
\text { rate }\end{array}$ & $\begin{array}{c}\text { Domestic } \\
\text { credit }\end{array}$ & Trade & Exports & $\begin{array}{c}\text { Foreign } \\
\text { aid }\end{array}$ & $\begin{array}{l}\text { Economic } \\
\text { openness }\end{array}$ & $\begin{array}{l}\text { Financial } \\
\text { deepening }\end{array}$ \\
\hline RHS variable (t) & $\begin{array}{c}-0.55 * * * \\
(0.161)\end{array}$ & $\begin{array}{c}0.20 * * * \\
(0.067)\end{array}$ & $\begin{array}{c}0.32 * * * \\
(0.079)\end{array}$ & $\begin{array}{c}0.35 * * * \\
(0.112)\end{array}$ & $\begin{array}{c}-0.25 * * * \\
(0.091)\end{array}$ & $\begin{array}{c}0.37 * * * \\
(0.132)\end{array}$ & $\begin{array}{c}0.25 * * * \\
(0.073)\end{array}$ \\
\hline Constant & $\begin{array}{c}22.68 * * * \\
(0.435)\end{array}$ & $\begin{array}{c}17.01 * * * \\
(1.416)\end{array}$ & $\begin{array}{c}14.30 * * * \\
(1.682)\end{array}$ & $\begin{array}{c}14.22 * * * \\
(2.222)\end{array}$ & $\begin{array}{c}26.61 * * * \\
(2.003)\end{array}$ & $\begin{array}{c}20.42 * * * \\
(0.304)\end{array}$ & $\begin{array}{c}20.61 * * * \\
(0.182)\end{array}$ \\
\hline Trend & $\begin{array}{c}0.08 * * * \\
(0.001)\end{array}$ & $\begin{array}{c}0.06 * * * \\
(0.006)\end{array}$ & $\begin{array}{c}0.05 * * * \\
(0.006)\end{array}$ & $\begin{array}{c}0.04 * * * \\
(0.011)\end{array}$ & $\begin{array}{c}0.07 * * * \\
(0.003)\end{array}$ & $\begin{array}{c}0.06 * * * \\
(0.005)\end{array}$ & $\begin{array}{c}0.06 * * * \\
(0.004)\end{array}$ \\
\hline \multicolumn{8}{|l|}{$\begin{array}{l}\text { ECM estimations with } \\
\Delta \text { capital formation (t): }\end{array}$} \\
\hline$\Delta$ capital formation $(\mathrm{t}-1)$ & & $\begin{array}{c}0.27 * * \\
(0.12)\end{array}$ & & & $\begin{array}{l}0.27 * * \\
(0.114)\end{array}$ & & $\begin{array}{l}0.28 * * \\
(0.113)\end{array}$ \\
\hline$\Delta$ RHS variable $(\mathrm{t})$ & $\begin{array}{c}0.04 \\
(0.081)\end{array}$ & $\begin{array}{c}0.07 * * \\
(0.03)\end{array}$ & $\begin{array}{c}0.14 * * * \\
(0.032)\end{array}$ & $\begin{array}{c}0.13 * * * \\
(0.034)\end{array}$ & $\begin{array}{c}-0.03 \\
(0.023)\end{array}$ & $\begin{array}{c}0.11 * * * \\
(0.028)\end{array}$ & $\begin{array}{c}0.10 * * * \\
(0.037)\end{array}$ \\
\hline$\Delta$ Trend & $\begin{array}{c}0.03 * * * \\
(0.006)\end{array}$ & $\begin{array}{c}0.02 * * * \\
(0.005)\end{array}$ & $\begin{array}{c}0.02 * * * \\
(0.005)\end{array}$ & $\begin{array}{c}0.014 * * \\
(0.006)\end{array}$ & $\begin{array}{c}0.02 * * * \\
(0.005)\end{array}$ & $\begin{array}{c}0.02 * * * \\
(0.006)\end{array}$ & $\begin{array}{c}0.03 * * * \\
(0.006)\end{array}$ \\
\hline $\operatorname{ECM}(t-1)$ & $\begin{array}{c}-0.37 * * * \\
(0.070)\end{array}$ & $\begin{array}{c}-0.37 * * * \\
(0.083)\end{array}$ & $\begin{array}{c}-0.43 * * * \\
(0.068)\end{array}$ & $\begin{array}{c}-0.36 * * * \\
(0.069)\end{array}$ & $\begin{array}{c}-0.30 * * * \\
(0.069)\end{array}$ & $\begin{array}{c}-0.31 * * * \\
(0.069)\end{array}$ & $\begin{array}{c}-0.40 * * * \\
(0.085)\end{array}$ \\
\hline Estimation model & $\begin{array}{c}\text { ARDL } \\
(1,1)\end{array}$ & $\begin{array}{c}\text { ARDL } \\
(2,0)\end{array}$ & $\begin{array}{c}\text { ARDL } \\
(1,0)\end{array}$ & $\begin{array}{c}\text { ARDL } \\
(1,0)\end{array}$ & $\begin{array}{c}\text { ARDL } \\
(2,1)\end{array}$ & $\begin{array}{c}\text { ARDL } \\
(1,0)\end{array}$ & $\begin{array}{c}\text { ARDL } \\
(2,0)\end{array}$ \\
\hline Adjusted $\mathrm{R}^{2}$ & 0.64 & 0.64 & 0.63 & 0.59 & 0.65 & 0.60 & 0.65 \\
\hline \multicolumn{8}{|l|}{ Diagnostic tests: } \\
\hline A: Serial Correlation: $\chi 2(1)$ & $\begin{array}{c}1.01 \\
{[0.31]}\end{array}$ & $\begin{array}{c}0.11 \\
{[0.75]}\end{array}$ & $\begin{array}{c}3.16 \\
{[0.08]}\end{array}$ & $\begin{array}{c}0.89 \\
{[0.35]}\end{array}$ & $\begin{array}{c}1.26 \\
{[0.26]}\end{array}$ & $\begin{array}{c}0.41 \\
{[0.52]}\end{array}$ & $\begin{array}{c}0.23 \\
{[0.63]}\end{array}$ \\
\hline B: Functional Form: $\chi 2(1)$ & $\begin{array}{c}0.63 \\
{[0.43]}\end{array}$ & $\begin{array}{c}1.31 \\
{[0.25]}\end{array}$ & $\begin{array}{c}0.42 \\
{[0.52]}\end{array}$ & $\begin{array}{c}0.64 \\
{[0.43]}\end{array}$ & $\begin{array}{c}4.38 \\
{[0.04]}\end{array}$ & $\begin{array}{c}0.17 \\
{[0.68]}\end{array}$ & $\begin{array}{c}0.32 \\
{[0.57]}\end{array}$ \\
\hline C: Normality: $\chi 2(2)$ & $\begin{array}{c}2.08 \\
{[0.35]}\end{array}$ & $\begin{array}{c}2.56 \\
{[0.28]}\end{array}$ & $\begin{array}{c}1.31 \\
{[0.52]}\end{array}$ & $\begin{array}{c}1.44 \\
{[0.49]}\end{array}$ & $\begin{array}{c}1.32 \\
{[0.52]}\end{array}$ & $\begin{array}{c}2.30 \\
{[0.32]}\end{array}$ & $\begin{array}{c}1.27 \\
{[0.53]}\end{array}$ \\
\hline D: Heteroskedasticity: $\chi 2(1)$ & $\begin{array}{c}1.75 \\
{[0.19]}\end{array}$ & $\begin{array}{c}0.65 \\
{[0.42]}\end{array}$ & $\begin{array}{c}0.23 \\
{[0.63]}\end{array}$ & $\begin{array}{c}0.28 \\
{[0.60]}\end{array}$ & $\begin{array}{c}2.71 \\
{[0.10]}\end{array}$ & $\begin{array}{c}0.19 \\
{[0.66]}\end{array}$ & $\begin{array}{c}0.78 \\
{[0.38]}\end{array}$ \\
\hline
\end{tabular}

Note: RHS means right hand side, and ECM error correction model. $\Delta$ denotes the first order difference operator. $*$, **, and *** indicate that the coefficients are significant at the $10 \%, 5 \%$, and $1 \%$ levels, respectively. The SBC selects the order of the ARDL models. In diagnostic tests, the nulls are: (A) no serial correlation, (B) no functionalform misspecification, (C) no non-normal errors, and (D) no heteroskedasticity. The LM version of diagnostic statistics show their res pective $p$-values in brackets under each statistic (see Pesaran and Pesaran 1997, Ch. 18 for details). Source: WDI 2012.

The long-run coefficient on foreign aid is negative, implying that investment rises if aid goes down. A note of caution should be made in this regard. Historically, the amount of foreign aid has been gradually evaporating over time. Bangladesh has been making a great deal of progress in self-financed investment and growth. The series of foreign aid and capital formation have shown a divergent pattern. Hence, this negative relationship between foreign aid and capital formation is more of a pattern rather than causality. We also notice that all the estimations, except for the one with foreign aid, in Table 3 are free of the misspecification in the function form. In addition, there is a trace of heteroskedasticity at the 10 percent level in the equation with foreign aid, implying that the estimates under foreign 
aid are likely to be non-robust. Consequently, the equation can be ignored in considering the investment determinants in this discussion.

All other estimations are free of serial correlation, heteroskedasticity, and non-normal errors, as shown under the diagnostic tests in Table 3. Adjusted R-squared values for all estimations are quite respectable, ranging from 59 to 65 percent. The SBC selected all the parsimonious models, which are stable in the long run, because the ECM values are all negative and significant, as required for stability. They range from -0.40 to 0.31 , suggesting that if the longrun relation is ever shocked, the robust values of the ECM will bring the system back in equilibrium in around three years or less.

\subsection{Policy implications}

The finding on the significant long-run effect of the interest rate on investment is important in that some previous studies provided confounding results in this regard. It also dispels the confusion in the national budget document that argues that high interest rates are not likely to impede investment in Bangladesh (Budget 2012:10). The central bank of the country should promote policy to reduce interest rates across the board. Commercial banks in Bangladesh argue that they cannot reduce the lending rate because of high deposit rates, on which they have to maintain a spread or difference to earn their income for administration and profit. The central bank cannot turn this point down. Rather, the central bank should try to reduce the whole interest rate spectrum so that the operations of the commercial banks become feasible.

Because high lending rates is not simply the presence of high deposit rates or a considerable amount of spread. The reason also lies in institutional factors such as bureaucracy, corruption, and excessive regulations, as argued in Dollar et al. (2005). Only the central bank cannot solve these issues unless the government becomes sincere enough to address them. Financial deregulation and prudent government policy that arguably can reduce the lending rate would be beneficial for the country to finance investment and to spur faster growth.

Since domestic credit expansion has a positive impact on capital formation, the central bank can nurture credit promotion policies to enhance the growth performance of the country. Although trade is beneficial for capital formation, the export sector needs preferential treatment to earn foreign capital and promote growth. There should not be any policy dilemma about economic openness, which lies at the root of investment augmentation and growth acceleration particularly since the early 1990s, as also shown in Siriwardana and Yang (2007) and De etal. (2012).

Apart from these interpretations, the government must ensure macro stability, which again depends on political stability, to create a vigorous investment climate. East Asian economies harvested the benefits of public policy and political stability in boosting investment (see WB 1993). Political instability has always affected investment adversely in Bangladesh. There is no exception to this rule in any developing nations. Since most investment decisions take medium-to-long-term scenarios into account, entrepreneurs are reluctant to risk their new ventures when political uncertainty clouds the future. Accordingly, we have always observed some slowdown in investment during the periods of regime change, but there is no authentic time series on political instability. The construction of this series in an objective way may allow us to include a variable in the estimations of investment in the future.

\subsection{Conclusion}

While we observe a plethora of research on the investment-output nexus, studies on the determinants of capital formation are evidently scarce. This scarcity becomes even acute when newly emerging countries are considered. In Bangladesh, an emerging nation of South Asia, a comprehensive study on the short-run and long-run determinants of investment is conspicuously absent. This work fills that gap. Working over a relatively liberalized regime of Bangladesh from 1976 to 2010, this exercise engages an ARDL bounds test method. It finds that the lending rate has a long-run negative effect on capital formation in the country, but short-run effects are insignificant.

While domestic savings have no significant impact on investment, domestic credit has. The policies of liberalization and financial deregulation appear to have had a positive impact on capital formation in Bangladesh. Economic openness and financial deepening have shown positive and significant effect on capital formation in the country. Trade or, more specifically, export promotion has contributed to the capital building as expected. These findings have policy implications for other developing nations which aspire to accomplishing rapid capital formation for faster economic growth.

This work raises some additional questions such as: 1) what are the significant underlying channels of financial deepening and economic openness that promote capital formation in Bangladesh? 2) Why is the short-term relationship between lending rates and capital formation insignificant in Bangladesh? 3) Why cannot domestic saving play a significant role in capital formation in Bangladesh? 4) How to assess the impact of political 
uncertainty on capital formation in Bangladesh? These questions require further study and hence are left for future investigation.

\section{References}

Adeniyi, O., Omisakin, O., Egwaikhide, F.O., Oyinlola, A., 2012. Foreign direct investment, economic growth and financial sector development in small open developing economies. Economic Analysis and Policy, 42(1):105128.

Ahmed, S., Islam, Md. E., 2004.Interest rate responsiveness of investment spending in Bangladesh. Bangladesh Development Studies, 30(1-2):67-109.

Ahmed, S., Sattar, Z., 2004.Trade liberalization, growth and poverty reduction: The case of Bangladesh.South Asia Discussion Paper No.IDP-190, World Bank, Washington.

Ahmed, H.A., Uddin, M.G.S., 2009. Export, imports, remittance and growth in Bangladesh: An empirical analysis. Trade and Development Review, 2(2):79-92.

Bhattacharyay, B., De, P., 2005. Promotion of trade and investments between China and India: The case of Southwest China and East and Northeast India, CESifo working paper no. 1508. http://www.cesifo.de/DocCIDL/cesifo1_wp1508.pdf

Bentzen I., Engsted T., 2001. A revival of the autoregressive distributed lag model in estimating energy demand relationships. Energy 26:45-55.

Budget, 2012. 2012-2013 Budget Speech by AMA Muhith, Finance Minister, Ministry of Finance, Government of Bangladesh, 1-149. http://mof.gov.bd/en/budget/12_13/budget_speech/speech_en.pdf

Choi, I., Chung, B., 1995. Sampling frequency and the power of tests for a unit root: A simulation study. Economics Letters, 49:131-36.

Cole, S., 2009. Financial development, bank ownership, and growth: Or, does quantity imply quality? Review of Economics and Statistics. 91(1):33-51.

Correa, R., Rao, D.T., 2004. Saving, lending and interest rates: A critique of financial liberalization in India. International Review of Applied Economics, 18(3):289-99.

Das, A., Paul, B. P., 2011. Openness and growth in emerging Asian economies: Evidence from GMM estimations of a dynamic panel. Economics Bulletin, 31(3):2219-28.

De, P., Raihan, S., Kathuria, S., 2012. Unblocking Bangladesh-India trade: Emerging potential and the way forward. World Bank Policy Research WP 6155. World Bank, Washington.

Dickey, D, Fuller, W.A., 1979. Distribution of the estimates for autoregressive time series with a unit root.Journal of the American Statistical Association, 74:427-431.

Dickey, D., Fuller, W.A., 1981. Likelihood ratio statistics for autoregressive time series with a unit root.Econometrica, 49:1057-72.

Din, M., Ghani, E., Siddique, O., 2003. Openness and economic growth in Pakistan. Pakistan Development Review, 42(4):795-807.

Dollar, D., Hallward-Driemeier, M., Mengistae, T., 2005.Investment climate and firm performance in developing economies. Economic Development and Cultural Change. 54(1):1-31.

Enders, W., 2010.Applied econometric time series, 3e, John Wiley and Sons, New Jersey.

Ghatak, S., Siddiki, J., 2001.The use of ARDL approach in estimating virtual exchange rates in India. Journal of Applied Statistics, 28:573-583.

Harrison, A., 1996. Openness and growth: A time-series, cross-country analysis for developing countries. Journal of Development Economics, 48:419-47.

Johansen, S., Juselius, K., 1990.Maximum likelihood estimation and inference on cointegration with application to the demand for money. Oxford Bulletin of Economics and Statistics, 52:169-209.

Kamal, M., 2011.Interest rate and investment in Bangladesh: An empirical analysis. Bank Parikrama, 36(2-4):1-10.

Krugman, P., 1994. The myth of Asia's miracle. Foreign Affairs, Nov-Dec, 73(6):62-78.

Liu, X., Song, H., Romilly, P., 1997.An empirical investigation of the causal relationship between openness and economic growth in China. Applied Economics, 29:1679-86.

Lutkepohl, H., 1985. Comparison of criteria for estimating the orders of a vector autoregressive process. Journal of Time Series Analysis, 6:35-52.

Maddala, G. S, Kim, I. M., 1998.Unit Roots, cointegration, and structural change, Cambridge University Press.

Mamun, K.A.A., Nath, H.K., 2005. Export-led growth in Bangladesh: A time series analysis. Applied Economics Letters, 12:361-364.

Naqvi, N.H., Tsoukis, C., 2003. Does public investment crowd out private investment? Evidence on investment and growth in Asia, 1971-2000. European Research Studies, 6(1-2):65-79.

Narayan, P.K., 2005. The saving and investment nexus for China: evidence from cointegration Tests. Applied Economics, 37(17):1979-1990. 
Odhiambo, N.M., 2008. Energy consumption and economic growth nexus in Tanzania: An ARDL bounds testing approach. Energy Policy 37(2):617-622.

Parida, P. C., Sahoo, P., 2007. Export-Led growth in South Asia: A panel cointegration analysis. International Economic Journal, 21(2):155-75.

Paul, B.P., 2011. Revisiting export-led growth for Bangladesh: A synthesis of cointegration and innovation accounting. International Journal of Economics and Finance, 3(6):3-15.

Paul, B.P., 2012. Inflation-growth nexus: some bivariate EGARCH evidence for Bangladesh. Macroeconomics and Finance in Emerging Market Economies, 6(1):1-11.

Paul, B.P., 2013. Can Bangladesh grow faster than India? Journal of Bangladesh Studies, 15(1):15-27.

Pesaran M.H., Pesaran B., 1997.Working with Microfit 4.0: Interactive econometric analysis, Oxford University Press.

Pesaran B., Pesaran M.H., 2009.Time series econometrics using Microfit 5.0, Oxford University Press.

Pesaran MH, Shin Y., 1999. An autoregressive distributed lag modeling approach to cointegration analysis.in Econometrics and Economic Theory in the 20th Century: The Ragnar Frisch Centennial Symposium, Strom S (ed.). Cambridge University Press, 371-413.

Pesaran, M.H., Shin Y., Smith R.J., 2001.Bounds testing approaches to the analysis of level relationships. Journal of Applied Econometrics, 16:289-326.

Phillips, P. C., Perron, P., 1988. Testing for a unit root in time series regression. Biometrika, 75(2):335-46.

Qayyum, A., 2002. Demand for bank lending by the private business sector in Pakistan. Pakistan Development Review, 41(2):149-59.

Sahoo, P., Dash, R.K., 2012. Economic growth in South Asia: Role of infrastructure. Journal of International Trade and Economic Development, 21(2):217-52.

Sinha, D., Sinha, T., 2002.0penness, investment, and economic growth in Asia. Indian Economic Journal, 49(4):9095.

Siriwardana, M., Yang, J., 2007. Effects of proposed free trade agreement between India and Bangladesh. South Asia Economic Journal, 8(1):21-38.

Solow, R.M., 1956. A Contribution to the theory of economic growth. Quarterly Journal of Economics, 70:65-94.

Wadud, M. A., 2009. Financial development and economic growth: A cointegration and error-correction modeling approach for South Asian countries. Economics Bulletin, 29(3):1670-77.

WB, 1993. The East Asian miracle: Economic growth and public policy, A World Bank Policy Research Report, Oxford University Press.

WDI, 2012. World development indicators, World Bank, Washington, http://data.worldbank.org/datacatalog/world-development-indicators

Yanikkaya, H., 2003. Trade, openness and economic growth: A cross-country empirical investigation. Journal of Development Economics, 72:57-89. 